\title{
AN ASSESSMENT OF PROFESSIONAL PRACTICE TRAINING IN UNDERGRADUATE ARCHITECTURAL EDUCATION
}

\author{
Esra BOSTANCIOĞLU \\ İstanbul Kültür University, Turkey \\ ebostancioglu@iku.edu.tr \\ Kevser Kesim GEMCI \\ İstanbul Kültür University, Turkey \\ kesimkevser@windowslive.com
}

\begin{abstract}
The scope of the architectural profession, one of the oldest professions in human history, has changed with the advent of technology. Likewise, architectural education also changes and improves all the time. Accrediting bodies evaluate architectural education and improve them through competence activities. In this study, the requirements identified by National Architectural Accrediting Board (NAAB), an international accreditation body, and the national accreditation body Architecture Accreditation Board (MIAK) have been reviewed, upon which it has been found out that professional practice has an important share in architectural education but has not been the subject of current research. Therefore, the study aims to assess the situation in Turkey in terms of undergraduate architectural education with respect to professional practice and identify the weaknesses thereof, hence contributing to architectural education. In this context, the professional practice requirements among the NAAB and MIAK requirements have been reviewed and the areas that need to be covered in terms of professional practice within undergraduate architecture programmes have been identified. The professional practice courses in undergraduate architecture programmes and the course contents have been analysed to demonstrate the current situation of professional practice training in undergraduate architecture programmes in Turkey. The data for the analysis of courses and course contents have been gathered from the webpages of universities. Content analysis method has been used in assessing course contents.
\end{abstract}

Keywords: Professional Practice, Content Analysis, Architecture Undergraduate Programs, Compulsory Courses.

\section{MİMARLIK EĞİTIMINDE MESLEKİ UYGULAMAYA YÖNELIKK EĞITIMIN DEĞERLENDIRILMESİ}

\section{ÖZ}

İnsanlık tarihinin en eski mesleklerinden biri olan mimarlık mesleğinin kapsamı, teknolojinin gelişimi ile farklılaşmıştır. Bu bağlamda Mimarlık Eğitimi de sürekli gelişim ve değişim göstermektedir. Akreditasyon kuruluşları, mimarlık eğitimini değerlendirmek ve yetkinlik çalışmaları aracılığı ile geliştirmek üzere kurulmuştur. Çalışma kapsamında uluslararası akreditasyon kuruluşlarından NAAB ve ulusal akreditasyon kuruluşu MIAK'ın mimarlık eğitimi için belirlediği yeterlilikler değerlendirilerek, mesleki uygulamanın mimarlık eğitimi içinde önemli bir pay aldığı ancak mevcut araştırmalarda ele alınmadığı görülmüştür. Dolayısı ile, çalışma kapsamında Mimarlık lisans eğitiminde mesleki uygulamaya yönelik eğitimin Türkiye'deki durumunun değerlendirilmesi ve zayıf yönlerin ortaya çıkartılarak, mimarlık eğitimine katkı sağlanması hedeflenmiştir. Bu bağlamda, NAAB ve MIAK'ın yeterlilikleri içinde mesleki uygulamaya yönelik olanlar değerlendirilerek, Mimarlık 
lisans programlarında mesleki uygulamaya yönelik olarak bulunması gereken alanlar belirlenmiştir. Türkiye'deki Mimarlık lisans programlarında mesleki uygulamaya yönelik dersler ve ders içerikleri analiz edilerek, Türkiye'deki Mimarlık lisans programlarında mesleki uygulamaya yönelik durum ortaya konmuştur. Derslerin ve ders içeriklerinin analiz edilebilmesi kullanılan veriler üniversitelerin web sayfalarından elde edilmiştir. Ders içeriklerinin değerlendirilmesinde içerik analizi yöntem olarak kullanılmıştır.

Anahtar Kelimeler: Mesleki Uygulama, İçerik Analizi, Mimarlık Lisans Programı, Zorunlu Dersler.

\section{INTRODUCTION}

The architectural profession is dynamic, open to new developments, and constantly goes through changes. It is a profession that can be exercised successfully by thinking about and planning structures and spaces, by installing amenities to ensure conditions for comfort while taking also into consideration cultural and geographical variables, and by adopting the right progressive organization, being disciplined, and assuming different roles (Akca et al., 2018) The discipline of architecture usually has to deal with issues with blurry lines, the solutions to which can be found in other disciplines and are related to many different fields. That is why architects need to possess wideranging and interdisciplinary qualifications (Foque, 2009). Technological changes, urbanization, economic and industrial developments, and the neo-liberal system of the 1990s introduced new complexities to the architectural profession and architectural education (Allen, 2012).

Architectural curricula should become globalized to cover the whole scope of architecture and the notion of structural integration and should only be localized in certain focus areas. Education and practice processes should be streamlined and merged, and it should be ensured that educational institutions are in continuous communication with the practice side so that architectural education can remain up-to-date with the developments taking place in professional practice (Nalcakan and Polatoglu, 2008).

Accreditation, in general, is a process of external review that evaluates colleges, universities and educational programs for quality and improvement ( $\mathrm{https}$ ://www.naab.org/accreditation/information/). Accreditation systems include standards that increase the frequency of international culturaleducational networks, facilitate their growth, and guide them. This control mechanism, by promoting originality, suggests that standards be adaptable and integrable components through diversity and flexibility. Any understanding, knowledge, skill, or behaviour, or in a more comprehensive sense, any qualification that each course is expected to impart to students in formal curricula, can be regarded as the holistic reflection of that course's learning outcomes on the student (Masatlioglu, 2008). According to Foque (2009), skills can only function effectively if they guide knowledge to be transferred into professional practice and this is supported by the correct professional conduct (Foque, 2009).

This study takes as a basis the criteria identified by National Architectural Accrediting Board (NAAB) in the USA, one of the most important international accrediting bodies, and the national accrediting body Architecture Accreditation Board (MIAK), in terms of their expectations from architectural education. In NAAB's framework, the student performance criteria that must be met in architectural education are composed of 26 criteria - eight under "Critical Thinking and Representation", 10 under "Building Practices, Technical Skills and Knowledge", three under "Integrated Architectural Solutions", and five under "Professional Practice". Within the accreditation conditions of MIAK, the knowledge and skills that must be obtained in architectural education are composed of 28 criteria four under "Architecture- Design/Creative Thinking", three under "Architecture- History/ Theory, Culture/Art", three under "Architecture- Environment/Urbanization/ Society", seven under "Architecture- Technology", and 11 under "Architecture- Professional Environment". It is expected that five of the 26 NAAB criteria and 11 of the 28 MIAK criteria will be acquired through professional 
practice training, which should occupy a large place in architectural education. Upon examination of the research conducted into architectural education in the past five years, it can be seen that research has focused on architectural design education. The studies on architectural education have focused on architectural design (Rodrigues, Hudson and Niblock, 2018; Masatlioglu, 2008), basic design (Uysal \& Topaloglu, 2017) and computer aided design relation with architectural design (Safari \& Abdollah, 2018; Benner \& McArthur, 2018). Despite the topics related to professional practice being discussed in architectural education conventions in Turkey, research or theses on the issue could not be found. Therefore, this study aims to assess the situation in Turkey in terms of undergraduate architectural education with respect to professional practice, which occupies an important place in overall architectural education, and identify the weaknesses thereof, hence contributing to architectural education.

The study first focuses on the concept of professional practice in architecture and identifies the subject areas vis-à-vis professional practice. Compulsory professional practice training courses on the webpages of universities providing architectural education in Turkey have been analysed in terms of course titles, course hours, ECTS credits, and the semesters in which they are taught. Then, using the subject areas identified in light of the knowledge and skills that need to be obtained in accordance with NAAB and MIAK criteria, the content of the professional practice training courses in undergraduate architecture programmes have been analysed using the content analysis method, hence painting an overall picture of the undergraduate architecture programmes in Turkey. Internship has been analysed separately as it is in fact part of the professional practice training and has been added to the curriculum of universities with the Bologna process but has still been assigned zero credits in some universities.

\section{PROFESSIONAL PRACTICE TRAINING IN ARCHITECTURAL EDUCATION}

Architecture is artistic as much as it is technical and productive and it creates the workforce necessary for the establishment of healthy spaces that ensure social welfare. In addition, architecture is the art of forming the relation between the physical environment in which people are going to live and the social environment (Ergul, 2015). As a discipline that is at the intersection of the disciplines of design and engineering, architecture is a profession that is dynamic, open to new developments, and that constantly changes (Locke, 1994). Architecture is one of the oldest professions in human history and have changed in time in response to economic, social, and technological developments. With the developments in communication and technology, expectations from architectural services have intensified and the subjects going into the scope of architecture have increased in number. As in other sectors, in the construction sector too, only the institutions that can bring together creativity and innovation can produce real value and therefore have a competitive advantage (Harrington et al., 1998). One can come across many studies looking into the knowledge and skills needed in the construction sector. The conclusions arrived at in these studies suggest that in addition to academic success, the sector also expects graduates to demonstrate teamplay, leadership capacity, outstanding individual qualities, information technology skills, foreign language command, problem solving skills, and awareness about the work environment (Warszawski, 1984; Ring 1988).

Accrediting bodies were established to evaluate architectural education and improve them through competence activities. In the scope of this study, the professional practice requirements among the requirements of the international accrediting body NAAB and the national accrediting body MIAK will be reviewed. The main purpose of MIAK is to evaluate architectural education and to improve it through competence activities. In this way, it is desired that better educated architects with the capacity to perform higher quality work will be trained, hence advancing social welfare. Whether accreditation is requested by the educational institution itself or is required by authorized institutions, it strives to ensure that the standards adopted by those who successfully complete the educational programme and graduate in terms of necessary design, technical, and professional skills and ethical principles are adequate. 


\section{NAAB Requirements for Architectural Programs}

NAAB accreditation is the primary means by which professional degree programs in architecture assure quality to students and the public (https://www.naab.org/accreditation/information/). NAAB identified educational outcomes for curriculum in the "Educational Outcomes and Curriculum" part of the "2014 Conditions for Accreditation" document. The accredited degree program must demonstrate that each graduate possesses the knowledge and skills defined by the criteria identified. The program must provide student work as evidence that its graduates have satisfied each criterion. The criteria encompass two level of accomplishment as understanding and ability. The NAAB establishes Student Performance Criteria (SPC) prepare students for the profession while encouraging education practices suited to the individual degree program. The SPC are organized into realms to be more easily understand the relationships between each criterion. Four realms are "Critical Thinking and Representation", "Building Practices, Technical Skills and Knowledge", "Integrated Architectural Solutions" and "Professional Practice". According to the NAAB, graduates from NAAB-accredited programs must understand business principles for the practice of architecture, including management, advocacy and the need to act legally, ethically and critically for the good of the client, society and the public (https://www.naab.org/wp-content/uploads/01 Final-Approved-2014-NAAB-Conditions-forAccreditation-2.pdf).

In this realm, each graduate possesses some skills in the following areas by the accredited degree program. These skills are seen in Table 1.

Table 1. Skills that must be possessed in the "Professional Practice" realm (NAAB criteria) (https://www.naab.org/wp-content/uploads/01_Final-Approved-2014-NAAB-Conditions-forAccreditation-2.pdf).

\begin{tabular}{|c|l|}
\hline $\begin{array}{c}\text { Stakeholder Roles in } \\
\text { Architecture }\end{array}$ & $\begin{array}{l}\text { Understanding the relationships among key stakeholders in the design } \\
\text { process- client, contractor, architect, user groups, local community- and } \\
\text { the architect's role to reconcile stakeholder needs. }\end{array}$ \\
\hline Project Management & $\begin{array}{l}\text { Understanding of the methods for selecting consultants and assembling } \\
\text { teams; identifying work plans, project schedules and time requirements } \\
\text { and recommending project delivery methods. }\end{array}$ \\
\hline Business Practices & $\begin{array}{l}\text { Understanding of the basic principles of a firm business practices, } \\
\text { including financial management and business planning, marketing, } \\
\text { organization and entrepreneurship. }\end{array}$ \\
\hline Legal Responsibilities & $\begin{array}{l}\text { Understanding of the architect's responsibility to the public and the client } \\
\text { as determined by regulations and legal considerations involving the } \\
\text { practice of architecture and professional service contracts. }\end{array}$ \\
\hline Professional Conduct & $\begin{array}{l}\text { Understanding of ethical issues involved in the exercise of professional } \\
\text { judgment in architectural design and practice and understanding the role of } \\
\text { the NCARB Rules of Conduct and the AIA Code of Ethics in defining } \\
\text { professional conduct. }\end{array}$ \\
\hline
\end{tabular}

Architecture Accreditation Board (MIAK) Requirements for Architectural Programs

The main objective of the Architecture Accreditation Board (MIAK) in Turkey is to develop architectural education through evaluation and accreditation studies. In this way, it is aimed to improve the welfare of the society by educating better educated and upgraded architects in Turkey. At this point, MIAK defines the content that should be given in architecture as program outcomes.

Architectural education must aim to produce professionals that can develop tactics and design strategies for knowledge generation in interdisciplinary work, can think creatively, are entrepreneurial, can take risks; have a sense of ethical responsibility and a critical outlook in respect of their employer, the society, public good, and legal limitations; and have cooperation and leadership capabilities (http://www.miak.org/). 
Table 2. Skills that must be possessed in the "Architecture-Professional Environment" realm (MIAK criteria) (http://www.mo.org.tr/miak/belge/dsp-Akreditasyonkosul.pdf)

\begin{tabular}{|c|c|}
\hline $\begin{array}{l}\text { Programming and } \\
\text { Evaluation }\end{array}$ & $\begin{array}{l}\text { Ability to prepare and evaluate an architectural project program by } \\
\text { considering the public benefits in regards of client and user needs, } \\
\text { appropriate examplers, space and equipment requirements, financial } \\
\text { limitations, site conditions, relevant codes, laws and design principles. }\end{array}$ \\
\hline $\begin{array}{l}\text { Comprehensive Project } \\
\text { Development }\end{array}$ & $\begin{array}{l}\text { Ability to produce a comprehensive architectural project that demonstrates } \\
\text { to make design decisions across various scales. }\end{array}$ \\
\hline $\begin{array}{l}\text { Considering Building } \\
\text { Costs }\end{array}$ & Understanding the fundamentals of building construction and use costs. \\
\hline $\begin{array}{l}\text { Architect-Client } \\
\text { Relationship }\end{array}$ & $\begin{array}{l}\text { Understanding of the responsibility of the architect to elicit, understand } \\
\text { and reconcile the needs of the client, owner, user groups and the public } \\
\text { and community domains. }\end{array}$ \\
\hline Collaboration & $\begin{array}{l}\text { Ability to work in collaboration with others and in multidisciplinary teams } \\
\text { to successfully complete design projects. }\end{array}$ \\
\hline Project Management & $\begin{array}{l}\text { Understanding of the methods for competing for commissions, selecting } \\
\text { consultants and assembling teams and recommending project delivery } \\
\text { methods. }\end{array}$ \\
\hline Practice Management & $\begin{array}{l}\text { Understanding the basic principles in the architectural practice processes } \\
\text { like financial management, business planning, quality management, risk } \\
\text { management, discussion and reconciliation. }\end{array}$ \\
\hline Leadership & $\begin{array}{l}\text { Understanding of the techniques and skills architects use to work } \\
\text { collaboratively in the building design and construction process and on } \\
\text { environmental, social and aesthetic issues in their communities. }\end{array}$ \\
\hline $\begin{array}{l}\text { Legal Rights and } \\
\text { Responsibilities }\end{array}$ & $\begin{array}{l}\text { Understanding of the architects's responsibility to the public and the client } \\
\text { as determined by regulations and legal considerations involving the } \\
\text { practice of architecture. }\end{array}$ \\
\hline Professional Practice & $\begin{array}{l}\text { Understanding and fulfillment of employer and intern rights and } \\
\text { responsibilities for development of profession }\end{array}$ \\
\hline Ethics of Profession & $\begin{array}{l}\text { Understanding of the ethical issues involved in profession regarding } \\
\text { social, political and cultural issues in architectural design and practice. }\end{array}$ \\
\hline
\end{tabular}

\section{METHODOLOGY}

The study has analysed the compulsory professional practice training courses of universities providing architectural education in Turkey in terms of course titles, the semesters in which they are taught, weekly course hours, and ECTS credits, and has analysed course contents by using the content analysis method.

Content analysis is a method of analyzing written, verbal or communication messages (Cole, 1988). It allows the researcher to test theoretical issues to enhance understanding of the data. Through content analysis, it is possible to distil words into fewer content related categories. It is assumed that when classified into the same categories, words, phrases and the like share the same meaning (Cavanagh 1997). It is the systematic examination of text and field notes by identifying and grouping themes and coding, classifying and developing categories (Jonge et.al., 2007). In qualitative content analysis the results are presented as categories and/or themes. In the literature there are various and sometimes confusing descriptions, with the cancepts sometimes used interchangeably, and the degrees of interpretation and levels of abstraction are inconsistent (Graneheim, et.al., 2017). In the past ten years, 105 theses using the content analysis method have been written. In 2017, the number of theses in which the content analysis method was used is 19, which represents an important increase from previous years. This indicates that the content analysis method has been gaining popularity in scientific research. A look at the research conducted shows that content analysis has been used in many areas and the data selected generally come from webpages, newspapers, magazines, articles, 
interviews, syllabi, coursebooks, and questionnaires. Content analysis is used in many fields like education, health, tourism, social life etc. for analyzing, measuring, evaluating and comparing the data. For all these reasons, content analysis has been deemed appropriate for the purposes of this study and used.

\section{Sample Identification}

The sample has been selected as all the universities providing undergraduate architectural education in Turkey. In order to reach the data, the curriculum and the content of the professional practice courses on the webpages of the undergraduate architecture programmes of universities have been used.

According to the statistical data on the webpage of the Council of Higher Education (YÖK), as of September 2017, there are in total 206 universities in Turkey (http://www.yok.gov.tr/). 120 of these universities have undergraduate architecture programmes. 34 of the 120 universities with undergraduate architectural degree programmes do not admit students. Among the 86 universities which do admit students, the one with the lowest quota for the architecture programme admits 20 students. The one with the largest quota admits 190 students (English and Turkish departments together) to the undergraduate architecture programme. All the universities in Turkey taken together, the total quota reserved for the architecture programme in the 2017-2018 academic year is 6,887 . The curricula of 20 among the 86 universities could not accessed. Upon examination of the eight-semester syllabi of the remaining 66 universities, it has been observed that 15 universities do not have courses on construction management. In the other 51 universities professional practice courses are provided with various course titles.

Out of the 110 courses looked into in the study, 44 are taught in the $8^{\text {th }}$ semester, 31 in the $7^{\text {th }}, 12$ in the $6^{\text {th }}, 6$ in the $5^{\text {th }}, 5$ in the $4^{\text {th }}, 6$ in the $3^{\text {rd }}, 3$ in $2^{\text {nd }}$, and 2 in the $1^{\text {st }}$. The study could not find out the semester information for one course. It can be concluded that professional practice courses are mostly taught in the $8^{\text {th }}$ semester in Turkey.

63 compulsory courses on professional practice have two weekly course hours, 28 have three, 13 have four, one has five, and three have one. The study could not access course hour data on two courses. Upon examination of the total number of course hours allocated to professional practice in universities, it has been found that the largest number of course hours provided by a university is 11 per week, which is provided by a single university. When the arithmetic mean of the total number of course hours allocated to professional practice in undergraduate architecture programmes is calculated, it can be seen that 5 hours of professional practice courses are taught per university in a week. The relation between the number of course hours allocated to professional practice courses in undergraduate architecture programmes and the total number of course hours per university is provided in Table 3.

Table 3. Assessment of Compulsory Professional Practice Courses

\begin{tabular}{|c|c|c|c|c|c|c|c|c|c|c|c|}
\hline & $\frac{3}{\stackrel{3}{\Xi}}$ & $\frac{3}{3}$ & $\frac{3}{\substack{\vdots \\
\vdots}}$ & $\frac{3}{\stackrel{3}{\Xi}}$ & $\begin{array}{l}3 \\
\stackrel{3}{\Xi} \\
\frac{0}{3} \\
n\end{array}$ & $\frac{3}{3}$ & $\frac{3}{\frac{3}{3}}$ & $\frac{3}{3}$ & $\frac{3}{\stackrel{3}{0}}$ & $\frac{3}{3}$ & $\begin{array}{l}3 \\
\stackrel{3}{0} \\
\vdots \\
\Xi \\
=\end{array}$ \\
\hline $\begin{array}{l}\text { Number of Professional Practice Courses in } \\
\text { Undergraduate Architecture Programmes }\end{array}$ & 3 & 63 & 28 & 13 & 1 & - & - & - & - & - & - \\
\hline $\begin{array}{l}\text { Breakdown of Total Number of Course Hours } \\
\text { Allocated to Professional Practice Courses by } \\
\text { Undergraduate Architecture Programmes }\end{array}$ & 1 & 4 & 11 & 4 & 7 & 7 & 2 & 8 & 4 & 1 & 1 \\
\hline $\begin{array}{c}\text { Average Course Hours for Professional Practice } \\
\text { Courses in Undergraduate Architecture Programmes }\end{array}$ & \multicolumn{11}{|c|}{5 hours/week } \\
\hline
\end{tabular}

Table 4 looks into 110 courses in terms of ECTS credits: there is one course with eight ECTS credits, 
four courses with six, 11 courses with five, 17 courses with four, 34 courses with three, 39 courses with two, and four courses with one ECTS credit. The course with the largest number of ECTS credits is the Construction Management and Economics course with 8 ETCS credits. The maximum number of ECTS credits allocated to professional practice courses in undergraduate architecture programmes in one semester is 8 and the minimum is 1 in Turkey. When universities are assessed on the basis of the total number of ECTS credits allocated to courses on professional practice, the largest number of ECTS credits allocated stands at 16. In universities with the smallest total number of credits per semester, that number is 2 ECTS credits. Assessment of compulsory professional practice courses by ECTS credits is presented in Table 4.

Table 4. Compulsory Professional Practice Courses by the Total Number of ECTS Credits

\begin{tabular}{|c|c|c|c|c|c|c|c|c|c|c|c|c|c|}
\hline & 帒 & 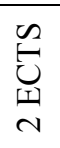 & $\begin{array}{l}\infty \\
\vdots \\
\substack{I \\
m} \\
m\end{array}$ & 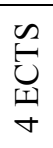 & $\underbrace{}_{\substack{\varphi \\
\text { I } \\
\text { in }}}$ & 帒 & 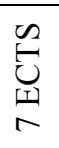 & $\underbrace{}_{\substack{\mathscr{\varphi} \\
\qquad \\
\infty}}$ & $\begin{array}{l}\infty_{1} \\
\bigcup_{1} \\
a\end{array}$ & 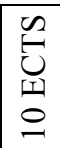 & $\begin{array}{l}n \\
0 \\
0 \\
i \\
=\end{array}$ & 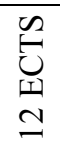 & $\begin{array}{l}0 \\
0 \\
0 \\
i=1 \\
0 \\
-1\end{array}$ \\
\hline $\begin{array}{l}\text { Number of Professional Practice Courses in } \\
\text { Undergraduate Architecture Programmes }\end{array}$ & 4 & 39 & 34 & 17 & 11 & 4 & - & 1 & - & - & - & - & \\
\hline $\begin{array}{c}\text { Total Credits of Compulsory Professional Practice } \\
\text { Courses by Undergraduate Architecture } \\
\text { Programmes }\end{array}$ & - & 6 & 6 & 2 & 4 & 11 & 4 & 4 & 4 & 4 & 1 & 3 & 2 \\
\hline $\begin{array}{c}\text { Credit Average of Compulsory Professional } \\
\text { Practice Courses in Undergraduate Architecture } \\
\text { Programmes }\end{array}$ & & & & & & & ECT & & & & & & \\
\hline
\end{tabular}

\section{Category Identification}

In content analysis, following the identification of the sample, categories have been determined as assessment criteria. The determination of the categories has been based on the international accrediting body NAAB and the national accrediting body MIAK's criteria on the requirements that need to be acquired in architectural education in terms of professional practice. 12 categories in total have been devised from the criteria under NAAB's "Professional Practice" and MIAK's "ArchitectureProfessional Environment" sections that a graduate of undergraduate architecture programmes must meet. These categories are;

- Project Delivery Systems

- Construction Contracts

- Project Planning Techniques

- Cost Estimation and Calculation Techniques

- Tender Process

- Building Production Process

- Quality Management

- Cost Management and Building Costs

- Risk Management

- Professional Practice

- Development Law and Legislation

- Leadership

While reviewing the course contents for professional practice, the study has also identified some categories that are not featured among the requirements that need to be fulfilled in undergraduate architectural education. These categories are related to courses at specialization and graduate levels and cover topical issues. Because these categories are in the course content, a separate analysis has been performed for these additional categories. While reviewing the course contents, 10 more categories have been added to the 12 categories. The added categories are;

- Site Management

Submit Date: 10.01.2019, Acceptance Date: 25.03.2019, DOI NO: 10.7456/10902100/008 
- Office Management

- Time and Resource Management

- Human Resource Management

- Supply Management

- Feasibility

- Occupational Health and Safety

- Construction Sector

- Participants of Building Production Process

- Information Management

The content of the compulsory professional practice courses in undergraduate architectural education programmes in Turkey have been assessed on the basis of two different category systems. Assesment of the courses in terms of first category system is seen in Tables 5. Moreover, internship has become compulsory in undergraduate programmes and has in fact become a compulsory course with credits in many universities with the Bologna process. Therefore, internship has also been added to the previously mentioned categories; hence, the state of play to do with internship in the undergraduate architecture programmes of 45 universities has also been assessed.

Table 5. Assessment of professional practice courses in terms of the first category system

\begin{tabular}{|c|c|c|c|c|c|c|c|c|c|c|c|c|c|}
\hline University & Course Name & 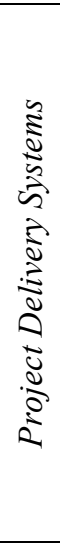 & $\begin{array}{l}0 \\
0 \\
0 \\
\vdots \\
0 \\
0 \\
0 \\
0 \\
0 \\
0 \\
0 \\
0 \\
0\end{array}$ & 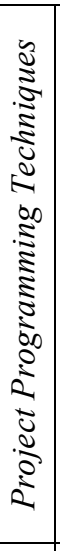 & 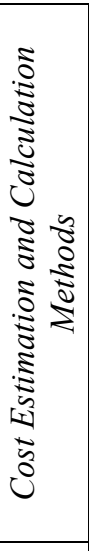 & 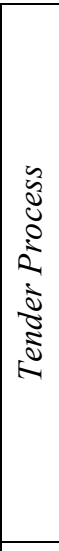 & 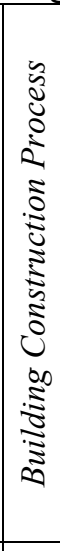 & 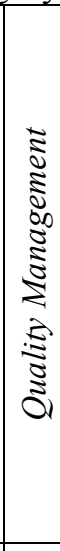 & 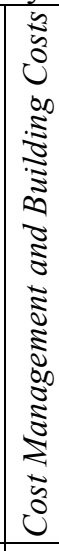 & 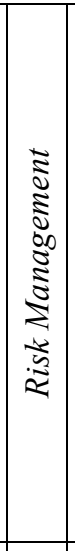 & 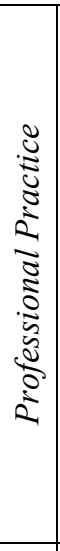 & 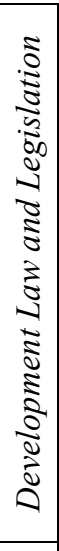 & 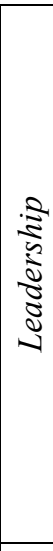 \\
\hline \multirow{2}{*}{ Akdeniz University } & $\begin{array}{l}\text { Project and Construction } \\
\text { Management }\end{array}$ & & & & & & $\mathrm{X}$ & & & & $\mathrm{X}$ & $\mathrm{X}$ & \\
\hline & Development Legislation & & & & & & & & & & & $\mathrm{X}$ & \\
\hline Altinbas University & $\begin{array}{l}\text { Construction Project } \\
\text { Management }\end{array}$ & & $\mathrm{X}$ & & & $X$ & $\mathrm{X}$ & $\mathrm{X}$ & $\mathrm{X}$ & & & $\mathrm{X}$ & $\mathrm{X}$ \\
\hline Anadolu University & $\begin{array}{l}\text { Construction Management } \\
\text { and Cost }\end{array}$ & & & $\mathrm{X}$ & $\mathrm{X}$ & & $\mathrm{X}$ & $\mathrm{X}$ & $\mathrm{X}$ & $\mathrm{X}$ & & & \\
\hline Atilim University & $\begin{array}{l}\text { Design and Project } \\
\text { Management }\end{array}$ & & & & & & $\mathrm{X}$ & $\mathrm{X}$ & & & & $\mathrm{X}$ & \\
\hline Balikesir University & $\begin{array}{l}\text { Construction Management } \\
\text { and Economics }\end{array}$ & $\mathrm{X}$ & & $\mathrm{X}$ & & $\mathrm{X}$ & & & & & & & $X$ \\
\hline Baskent University & $\begin{array}{l}\text { Professional Practice and } \\
\text { Management }\end{array}$ & & $\mathrm{X}$ & $\mathrm{X}$ & $X$ & $X$ & & & & & & $\mathrm{X}$ & \\
\hline \multirow{2}{*}{ Cukurova University } & $\begin{array}{l}\text { Professional Practice } \\
\text { Knowledge }\end{array}$ & & $\mathrm{X}$ & $\mathrm{X}$ & $\mathrm{X}$ & $\mathrm{X}$ & & & & & & $\mathrm{X}$ & \\
\hline & $\begin{array}{l}\text { Construction Management } \\
\text { and Economics }\end{array}$ & & $\mathrm{X}$ & $\mathrm{X}$ & & $\mathrm{X}$ & & & $\mathrm{X}$ & & & $\mathrm{X}$ & \\
\hline \multirow[t]{2}{*}{ Dogus University } & $\begin{array}{l}\text { Construction Management } \\
\text { and Economics }\end{array}$ & & & $\mathrm{X}$ & $\mathrm{X}$ & & & & $\mathrm{X}$ & & & & \\
\hline & Urban Development Law & & & & & & & & & & & $\mathrm{X}$ & \\
\hline
\end{tabular}

Submit Date: 10.01.2019, Acceptance Date: 25.03.2019, DOI NO: 10.7456/10902100/008 


\begin{tabular}{|c|c|c|c|c|c|c|c|c|c|c|c|c|c|}
\hline \multirow{2}{*}{ Duzce University } & $\begin{array}{l}\text { Construction Management } \\
\text { and Economics }\end{array}$ & & & & $\mathrm{X}$ & & & $\mathrm{X}$ & & $\mathrm{X}$ & & & $\mathrm{X}$ \\
\hline & $\begin{array}{l}\text { Design Ethics and } \\
\text { Development Law } \\
\end{array}$ & & & & & & & & & & & $\mathrm{X}$ & \\
\hline Erciyes University & \begin{tabular}{|l|} 
Economics and \\
Administration Buildings
\end{tabular} & & $\mathrm{X}$ & $\mathrm{X}$ & $\mathrm{X}$ & & $\mathrm{X}$ & & $\mathrm{X}$ & & & $\mathrm{X}$ & $\mathrm{X}$ \\
\hline \multirow{2}{*}{$\begin{array}{c}\text { Fatih Sultan Mehmet } \\
\text { University }\end{array}$} & $\begin{array}{l}\text { Construction Management } \\
\text { and Administration }\end{array}$ & $\mathrm{X}$ & $\mathrm{X}$ & $\mathrm{X}$ & & & $\mathrm{X}$ & & $\mathrm{X}$ & & & & \\
\hline & $\begin{array}{l}\text { Construction Project and } \\
\text { Building Law }\end{array}$ & & & & & & & & & & $\mathrm{X}$ & $\mathrm{X}$ & \\
\hline \multirow{3}{*}{ Firat University } & Project Management & $\mathrm{X}$ & $\mathrm{X}$ & $\mathrm{X}$ & & $\mathrm{X}$ & & & $\mathrm{X}$ & $\mathrm{X}$ & & & $\mathrm{X}$ \\
\hline & Cost Management & & & & $\mathrm{X}$ & & & & & & & & \\
\hline & $\begin{array}{l}\text { Development and Building } \\
\text { Law }\end{array}$ & & & & & & & & & & & $\mathrm{X}$ & \\
\hline Gazi University & $\begin{array}{l}\text { Construction Management } \\
\text { and Economics }\end{array}$ & & & $\mathrm{X}$ & $\mathrm{X}$ & & $\mathrm{X}$ & $\mathrm{X}$ & $\mathrm{X}$ & & & $\mathrm{X}$ & $\mathrm{X}$ \\
\hline \multirow{2}{*}{ Gaziantep University } & $\begin{array}{l}\text { Management and } \\
\text { Economics }\end{array}$ & & & & & & & & $\mathrm{X}$ & & & & \\
\hline & $\begin{array}{l}\text { General and Professional } \\
\text { Ethics } \\
\end{array}$ & & & & & & & & & & $\mathrm{X}$ & & \\
\hline \multirow{2}{*}{ Gebze Technical University } & $\begin{array}{l}\text { Construction Management } \\
\text { and Economics }\end{array}$ & $\mathrm{X}$ & $\mathrm{X}$ & $\mathrm{X}$ & $\mathrm{X}$ & & & $\mathrm{X}$ & $\mathrm{X}$ & $\mathrm{X}$ & & $\mathrm{X}$ & \\
\hline & $\begin{array}{l}\text { Labor and Public } \\
\text { Improvement Law } \\
\end{array}$ & & & & & & & & & & & $\mathrm{X}$ & \\
\hline \multirow[t]{2}{*}{ Halic University } & $\begin{array}{l}\text { Site Administration and } \\
\text { Building Cost }\end{array}$ & & $\mathrm{X}$ & & $\mathrm{X}$ & $\mathrm{X}$ & & & $\mathrm{X}$ & & & $\mathrm{X}$ & \\
\hline & Mesleki Hukuk & & & & & & & & & & & $\mathrm{X}$ & \\
\hline \multirow[t]{2}{*}{ Hasan Kalyoncu University } & $\begin{array}{l}\text { Construction Management } \\
\text { and Construction Site } \\
\text { Management }\end{array}$ & & & & $\mathrm{X}$ & & & & & & & & \\
\hline & $\begin{array}{l}\text { Construction Management } \\
\text { and Economics }\end{array}$ & $\mathrm{X}$ & $\mathrm{X}$ & $\mathrm{X}$ & $\mathrm{X}$ & & & $\mathrm{X}$ & $\mathrm{X}$ & & $\mathrm{X}$ & & $\mathrm{X}$ \\
\hline Isik University & $\begin{array}{l}\text { Construction Management } \\
\text { and Economics }\end{array}$ & & $\mathrm{X}$ & $\mathrm{X}$ & & & & $\mathrm{X}$ & $\mathrm{X}$ & & & & $\mathrm{X}$ \\
\hline $\begin{array}{c}\text { İhsan Dogramaci Bilkent } \\
\text { University }\end{array}$ & Professional Practice & & $\mathrm{X}$ & & & & & & $\mathrm{X}$ & & $\mathrm{X}$ & $\mathrm{X}$ & \\
\hline \multirow{4}{*}{ Istanbul Arel University } & $\begin{array}{l}\text { Construction Management } \\
\text { and Economics }\end{array}$ & $\mathrm{X}$ & $\mathrm{X}$ & $\mathrm{X}$ & $\mathrm{X}$ & & & & $\mathrm{X}$ & & $\mathrm{X}$ & & \\
\hline & $\begin{array}{l}\text { Professional Appliance- } \\
\text { Zoning Law }\end{array}$ & & & & & & & & & & & $\mathrm{X}$ & \\
\hline & $\begin{array}{l}\text { Quality Assurance and } \\
\text { Quality Management }\end{array}$ & & & & & & & $\mathrm{X}$ & & & & & \\
\hline & $\begin{array}{l}\text { Environmental Protection, } \\
\text { Occupational Safety and } \\
\text { Health }\end{array}$ & & & & & & & & & & & & \\
\hline \multirow{4}{*}{ Istanbul Aydin University } & Cost Control in Buildings & $\mathrm{X}$ & $\mathrm{X}$ & $\mathrm{X}$ & $\mathrm{X}$ & & & & $\mathrm{X}$ & & & & \\
\hline & $\begin{array}{l}\text { Professional Practice and } \\
\text { Ethics }\end{array}$ & & & & & & & & & & $\mathrm{X}$ & & $\mathrm{X}$ \\
\hline & $\begin{array}{l}\text { Project and Construction } \\
\text { Management }\end{array}$ & & & & & & & & & & & & $\mathrm{X}$ \\
\hline & $\begin{array}{l}\text { Occupational Health and } \\
\text { Safety }\end{array}$ & & & & & & & & & & & & \\
\hline
\end{tabular}

Submit Date: 10.01.2019, Acceptance Date: 25.03.2019, DOI NO: 10.7456/10902100/008 


\begin{tabular}{|c|c|c|c|c|c|c|c|c|c|c|c|c|c|}
\hline \multirow[t]{2}{*}{ Istanbul Bilgi University } & \begin{tabular}{|l|} 
Professional Practice \\
Management
\end{tabular} & $\mathrm{X}$ & $\mathrm{X}$ & $\mathrm{X}$ & $\mathrm{X}$ & $\mathrm{X}$ & $\mathrm{X}$ & & $\mathrm{X}$ & & & $\mathrm{X}$ & $\mathrm{X}$ \\
\hline & Codes and Regulations & & & & & & & & & & & $\mathrm{X}$ & \\
\hline \multirow{2}{*}{ Istanbul Esenyurt University } & $\begin{array}{l}\text { Construction Management } \\
\text { and Economics }\end{array}$ & & $\mathrm{X}$ & $X$ & $\mathrm{X}$ & $\mathrm{X}$ & & & $\mathrm{X}$ & & & $\mathrm{X}$ & \\
\hline & $\begin{array}{l}\text { Professional Practice } \\
\text { Knowledge }\end{array}$ & & $\mathrm{X}$ & & $\mathrm{X}$ & & & & & & $\mathrm{X}$ & $\mathrm{X}$ & \\
\hline \multirow{3}{*}{ Istanbul Kultur University } & Architectural Economics & & & & & & & & $\mathrm{X}$ & & & & \\
\hline & Construction Management & $\mathrm{X}$ & $\mathrm{X}$ & $\mathrm{X}$ & & $\mathrm{X}$ & & & & & & & \\
\hline & $\begin{array}{l}\text { Architecture and } \\
\text { Professional Practice }\end{array}$ & & & & & & & & & & & $\mathrm{X}$ & \\
\hline \multirow{4}{*}{ Istanbul Medipol University } & $\begin{array}{l}\text { Introduction to Project } \\
\text { Management }\end{array}$ & & $\mathrm{X}$ & & & & & $\mathrm{X}$ & $\mathrm{X}$ & & & & \\
\hline & Introduction to Profession & & & & & & & & & & $\mathrm{X}$ & & \\
\hline & Construction Management & $X$ & & $X$ & $\mathrm{X}$ & $\mathrm{X}$ & $\mathrm{X}$ & & $\mathrm{X}$ & & $\mathrm{X}$ & & $\mathrm{X}$ \\
\hline & Development Law & & & & & & & & & & & $\mathrm{X}$ & \\
\hline \multirow{4}{*}{$\begin{array}{c}\text { Istanbul Sabahattin Zaim } \\
\text { University }\end{array}$} & $\begin{array}{l}\text { Construction Management } \\
\text { and Economics }\end{array}$ & $X$ & & & $\mathrm{X}$ & & & & $\mathrm{X}$ & & & & \\
\hline & Development Law & & & & & & & & & & & $\mathrm{X}$ & \\
\hline & $\begin{array}{l}\text { Professional Practice and } \\
\text { Ethics }\end{array}$ & & & & & & & & & & $\mathrm{X}$ & & \\
\hline & Occupational Safety & & & & & & & & & & & & \\
\hline $\begin{array}{c}\text { Istanbul Technical } \\
\text { University }\end{array}$ & $\begin{array}{l}\text { Construction Management } \\
\text { and Economics }\end{array}$ & $\mathrm{X}$ & $\mathrm{X}$ & $\mathrm{X}$ & $\mathrm{X}$ & & $\mathrm{X}$ & $\mathrm{X}$ & $\mathrm{X}$ & $\mathrm{X}$ & $\mathrm{X}$ & $\mathrm{X}$ & $\mathrm{X}$ \\
\hline \multirow{2}{*}{$\begin{array}{c}\text { Istanbul Yeni Yuzyil } \\
\text { University }\end{array}$} & $\begin{array}{l}\text { Construction Management } \\
\text { and Cost }\end{array}$ & & & & $\mathrm{X}$ & & $\mathrm{X}$ & & $\mathrm{X}$ & & & & \\
\hline & $\begin{array}{l}\text { Professional Practice } \\
\text { Knowledge }\end{array}$ & & $\mathrm{X}$ & & & & & & & & $\mathrm{X}$ & $\mathrm{X}$ & \\
\hline $\begin{array}{c}\text { Karadeniz Technical } \\
\text { University }\end{array}$ & $\begin{array}{l}\text { Professional Practice } \\
\text { Knowledge }\end{array}$ & & & & $\mathrm{X}$ & $\mathrm{X}$ & & & & & $\mathrm{X}$ & $\mathrm{X}$ & \\
\hline Kirklareli University & $\begin{array}{l}\text { Building Production } \\
\text { Management and Cost }\end{array}$ & $\mathrm{X}$ & $\mathrm{X}$ & $\mathrm{X}$ & $\mathrm{X}$ & & & & $\mathrm{X}$ & & $\mathrm{X}$ & $\mathrm{X}$ & \\
\hline \multirow{5}{*}{ KTO Karatay University } & $\begin{array}{l}\text { Estimate of Cost and } \\
\text { Quantity Survey of } \\
\text { Buildings }\end{array}$ & & & & $\mathrm{X}$ & & & & & & & & \\
\hline & $\begin{array}{l}\text { Building Site Management } \\
\text { and Organization }\end{array}$ & & $\mathrm{X}$ & $\mathrm{X}$ & & & & & & & & & \\
\hline & $\begin{array}{l}\text { Construction Management } \\
\text { and Economics }\end{array}$ & & $\mathrm{X}$ & $\mathrm{X}$ & & & $\mathrm{X}$ & & & & & & \\
\hline & Occupational Ethics & & & & & & & & & & $\mathrm{X}$ & & \\
\hline & Work and Planning Law & & & & & & & & & & & $\mathrm{X}$ & \\
\hline \multirow{3}{*}{ Maltepe University } & Construction Management & $\mathrm{X}$ & $\mathrm{X}$ & $\mathrm{X}$ & $\mathrm{X}$ & & $\mathrm{X}$ & & $\mathrm{X}$ & $X$ & & & \\
\hline & $\begin{array}{l}\text { Occupational Health and } \\
\text { Safety I }\end{array}$ & & & & & & & & & $\mathrm{X}$ & & & \\
\hline & $\begin{array}{l}\text { Occupational Health and } \\
\text { Safety II }\end{array}$ & & & & & & & & & & & & \\
\hline \multirow[b]{2}{*}{ Mardin Artuklu University } & Development Law & & & & & & & & & & & $\mathrm{X}$ & \\
\hline & \begin{tabular}{|l|} 
Professional Practice \\
Knowledge
\end{tabular} & & & & & & & & & & $\mathrm{X}$ & & \\
\hline Mersin University & Construction Management & $\mathrm{X}$ & $\mathrm{X}$ & $\mathrm{X}$ & $\mathrm{X}$ & & $\mathrm{X}$ & $\mathrm{X}$ & $\mathrm{X}$ & $\mathrm{X}$ & $\mathrm{X}$ & $\mathrm{X}$ & $\mathrm{X}$ \\
\hline $\begin{array}{c}\text { Mimar Sinan Fine Arts } \\
\text { University }\end{array}$ & $\begin{array}{l}\text { Construction Management } \\
\text { and Economics }\end{array}$ & & & & $X$ & $\mathrm{X}$ & & $\mathrm{X}$ & $\mathrm{X}$ & & & & \\
\hline
\end{tabular}




\begin{tabular}{|c|c|c|c|c|c|c|c|c|c|c|c|c|c|}
\hline & Development Law & & & & & & & & & & & $\mathrm{X}$ & \\
\hline \multirow{2}{*}{$\begin{array}{l}\text { Necmettin Erbakan } \\
\text { University }\end{array}$} & $\begin{array}{l}\text { Occupational Health and } \\
\text { Safety I }\end{array}$ & & & & & & & & & & & & \\
\hline & $\begin{array}{l}\text { Occupational Health and } \\
\text { Safety II }\end{array}$ & & & & & & & & & & & & \\
\hline \multirow{3}{*}{$\begin{array}{c}\text { Nigde Omer Halisdemir } \\
\text { University }\end{array}$} & $\begin{array}{l}\text { Occupational Health and } \\
\text { Safety I }\end{array}$ & & & & & & & & & & & & \\
\hline & $\begin{array}{l}\text { Occupational Health and } \\
\text { Safety II }\end{array}$ & & & & & & & & & & & & \\
\hline & $\begin{array}{l}\text { Construction Management } \\
\text { and Economics }\end{array}$ & & $\mathrm{X}$ & & $\mathrm{X}$ & & & & & & $\mathrm{X}$ & $\mathrm{X}$ & \\
\hline Okan University & $\begin{array}{l}\text { Project and Construction } \\
\text { Management }\end{array}$ & $\mathrm{X}$ & $\mathrm{X}$ & $\mathrm{X}$ & $\mathrm{X}$ & & & $X$ & $\mathrm{X}$ & $X$ & $\mathrm{X}$ & $\mathrm{X}$ & \\
\hline $\begin{array}{l}\text { Middle East Technical } \\
\text { University }\end{array}$ & Profeccional Practice & $\mathrm{X}$ & & & $\mathrm{X}$ & & $\mathrm{X}$ & & $\mathrm{X}$ & & $\mathrm{X}$ & $\mathrm{X}$ & \\
\hline \multirow{3}{*}{ Ozyegin University } & $\begin{array}{l}\text { Construction Management } \\
\text { and Economics }\end{array}$ & & $\mathrm{X}$ & & & & & & $\mathrm{X}$ & $\mathrm{X}$ & & & $\mathrm{X}$ \\
\hline & Project Management & $\mathrm{X}$ & $\mathrm{X}$ & $\mathrm{X}$ & & $\mathrm{X}$ & $\mathrm{X}$ & & & & & & \\
\hline & Profession Law & & & & & & & & & & & $\mathrm{X}$ & \\
\hline \multirow[t]{2}{*}{ Selcuk University } & \begin{tabular}{|l|} 
Practice of Cost \\
Estimation and Quantity \\
Survey for Buildings \\
\end{tabular} & & $\mathrm{X}$ & & $\mathrm{X}$ & $\mathrm{X}$ & & & & & & $\mathrm{X}$ & \\
\hline & $\begin{array}{l}\text { Construction Management } \\
\text { and Economics }\end{array}$ & $\mathrm{X}$ & & $\mathrm{X}$ & & $\mathrm{X}$ & $\mathrm{X}$ & & & & & & $\mathrm{X}$ \\
\hline TED University & Profession and Practice & $\mathrm{X}$ & & & & & $X$ & & & & $\mathrm{X}$ & & \\
\hline \multirow{4}{*}{ Yasar University } & $\begin{array}{l}\text { Construction Project and } \\
\text { Management }\end{array}$ & & & $\mathrm{X}$ & & & & & $\mathrm{X}$ & & & & \\
\hline & Development Process & & $\mathrm{X}$ & & & & & & & & & $\mathrm{X}$ & \\
\hline & $\begin{array}{l}\text { Occupational Health and } \\
\text { Safety I }\end{array}$ & & & & & & & & & & & & \\
\hline & $\begin{array}{l}\text { Occupational Health and } \\
\text { Safety II }\end{array}$ & & & & & & & & & & & & \\
\hline \multirow{2}{*}{ Yeditepe University } & $\begin{array}{l}\text { Architectural Project } \\
\text { Management }\end{array}$ & & $\mathrm{X}$ & $\mathrm{X}$ & $\mathrm{X}$ & $\mathrm{X}$ & $\mathrm{X}$ & & $\mathrm{X}$ & & & & \\
\hline & $\begin{array}{l}\text { Concepts of Development } \\
\text { Applications }\end{array}$ & & & & & & & & & & & $\mathrm{X}$ & \\
\hline Yildiz Technical University & $\begin{array}{l}\text { Construction Management } \\
\text { and Economics }\end{array}$ & & & & $\mathrm{X}$ & & $\mathrm{X}$ & & & & & & \\
\hline
\end{tabular}

\section{Assessment of Units of Analysis}

Identified categories have been assessed on the basis of 103 compulsory courses on professional practice. Because we have not been able to access the course content of 21 of these courses, they have not been assessed. The content of the remaining 82 courses has been reviewed and the categories identified have been analysed based on the words in the course content. The data obtained can be seen in Table 5 .

\section{Determination of the Counting System}

Data in Table 5 have been assessed and the number of occurrences of categories has been established, which then has been demonstrated in a graph in Figure 1. As a result of the analysis performed; we have found out the number of times categories have been featured in the courses, the most frequently featured categories in the undergraduate architecture programmes in Turkey, the rate at which the knowledge and skills that need to be acquired through undergraduate education are met, and the 
missing categories.

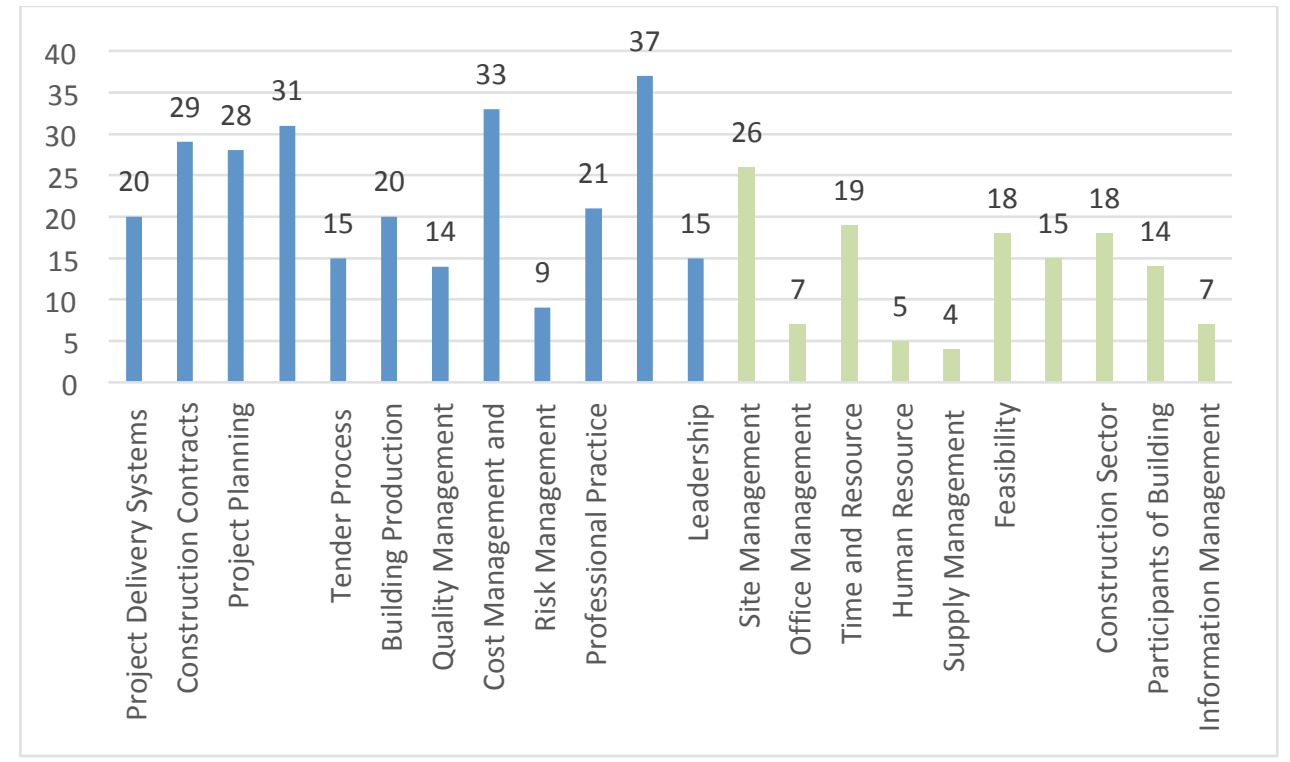

Figure 1. Number of occurrences of categories

\section{FINDINGS}

According to Figure 1, which has been created using the data in Table 5, the subject featuring the most frequently in undergraduate architecture programmes in Turkey is Development Law and Legislation which features in the content of the core courses of 37 out of 44 universities. This is followed by Cost Management and Building Costs, featuring in course content in 33 universities, and the subject of Construction Contracts, which features in 29 universities. The subject featuring the least frequently in the courses is Risk Management.

As a result of the analysis conducted, it has been ascertained that the course contents feature the requirements that need to be fulfilled most at the undergraduate level. Apart from these subjects, also featured frequently in course contents are Construction Site Management, Time and Resource Management, Feasibility and Construction Sector. It has been found out that subjects such as Sustainability in Human Resources Management and Information Management, which are only just starting to be discussed in our country, are featured in the course contents of very few universities.

As a result of the analysis, the study has not been able to find a category that is commonly present in the course content of all the 44 universities whose compulsory course content has been accessed; in fact, most of the categories are not even featured in half of the universities. This indicates the weaknesses in terms of the requirements that need to be fulfilled in undergraduate architectural studies in Turkey.

In addition to the compulsory professional practice courses, internship is also a compulsory course in many universities because of the Bologna process. Internship periods and the credits assigned thereto vary from university to university. The number of credits assigned to internship is 16 ECTS at the most and 0 ECTS at the least.

\section{CONCLUSION}

Professional practice courses in undergraduate architecture programmes in Turkey are featured in the syllabus of the last semester and have a weight of $0.025 \%$, with 6 ECTS credits, within a total of 240 
ECTS credits. Four universities assign the most credits to such courses with 12 ECTS credits. An examination of the contents of the compulsory professional practice courses in undergraduate architecture programmes in Turkey shows that the category that is most ubiquitous in courses is Development Law and Legislation. Course content of the Development Law and Legislation category is provided in 37 of the universities whose course content is accessible. The category that is featured the least frequently with respect to NAAB and MIAK requirements is the Risk Management category. Some universities do not have any compulsory professional practice courses in line with NAAB and MIAK requirements apart from internship. More than half of the professional practice requirements are covered in 19 out of 45 universities.

It can be concluded that despite having an important share in professional requirements, compulsory professional practice courses occupy a somewhat smaller place in undergraduate architecture programmes. Furthermore, in many of the universities where professional practice courses are taught, the course hours are very short and a small amount of the knowledge and skills that need to be obtained in undergraduate architectural education is actually imparted. Professional practice courses other than internships should be taught in all undergraduate architecture programmes in Turkey. Furthermore, the number and types of elective courses and the course hours can be increased, with the ECTS credits being increased in accordance with the foregoing. In addition, course contents can be made more comprehensive and the objective in the courses should be to ensure the acquisition of professional practice qualifications. This will lead to better equipped architects for the future. It is expected that the findings demonstrating the current situation in Turkey of the professional practice education in undergraduate architecture programmes will bear a torch for future research and will contribute to the development of education.

\section{REFERENCES}

Akca, Y. Berivan Ozbudak, Aydin, Derya Cakir, Halifeoglu,Fatma Meral.(2018) "Mimarlık Mesleğine Ulaşılabilirlikte Farkl Bir Araylş Denemesi: Dicle Üniversitesi Örneği (Alternative Approaches to Pursuing Architecture as a Profession: Dicle University Sample)", Electronic Journal of Social Sciences, 17(67), 1147-1158.

Allen, B. S. (2012). "The Future That Is Now: Architectural education in North America 1900-2010". In. J. Ockman (Ed.), Architecture School: Three centuries of educating architects in North America (pp. 203-229). MIT Press \& ACSA, Cambridge.

Benner, J., McArthur, J.J. (2018) "Lessons Learned from a Multi-year Initiative to Integrate DataDriven Design Using BIM into Undergraduate Architectural Education”, Proceedings of the 35th CIB W78 2018 Conference: IT in Design, Construction, and Management, Advances in Informatics and Computing in Civil and Construction Engineering, 857-864.

Cavanagh, S. (1997) "Content Analysis:Concepts, Methods and Applications", Nurse Researcher, 4, 5-16.

Cole, F.L. (1988) “Content Analysis: Process and Application”, Clinical Nurse Specialist, 2(1), $53-$ 57.

Ergul, H. (2015). “Mimarlı̆̆ı İhmal Edilen Sosyal ve Toplumsal Yönü”, Akademik Platform, ISITES 2015, Valencia-Spain.

Esen, Ece, Elibol, Gulcin Cankiz, Koca, Duygu (2018) "Basic Design Education and Bauhaus", The Turkish Online Journal of Design, Art and Communication-TOJDAC, 8(1), 37-44. DOI: 10.7456/10801100/004.

Foque, Richard. (2009). "Mimarlı Eğitiminde Yetkinliklere Dayalı Müfredat Programı Tasarımı için Bir Strateji” (N. Çağlar, Çev.). İ̧. N. Çağlar (Ed.), TMMOB Mimarlar Odası Ankara Şubesi Dosya 15: Mimari Tasarım Ĕgitimi, (s. 11-14).

Graneheim, U.H., Lindgren, B. \& Lundman, B. (2017). "Methodological Challenges in Qualitative Content Analysis: A Discussion Paper”, Nurse Education Today, 56, 29-34.

Harrington, H., Hoffherr, G. \& Reid, R.Jr. (1998). The Creativity Toolkit, McGraw-Hill, New York. 
Jonge, D., Scherer, M.J. \& Rodger, S. (2007). "Assistive Technology in the Workplace-Chapter 3Consumer-Centered Process for Technology Acquisition and Use", Elsevier, Inc. All, ISBN-978-0323-04130-0.

Nalcakan, Hande \& Polatoglu, Cigdem, (2008). "Türkiye'deki ve Dünyadaki Mimarlık Ĕ̈itiminin Karşılaştırmalı Analizi ile Küreselleşmenin Mimarlık Ë̆itimine Etkisinin İncelenmesi (Education of Architectural in World and Turkey with Comparison Analyses and the Effect of the Globalisation to the Architectural Education)", Megaron YTÜ Arc. Fac. E-Journal, 3(1), 79-103.

Riggs, L.S. (1988) "Educating Construction Managers", Journal of Management In Engineering, ASCE, 114(2), 279-285.

Rodriguez, Caroline, Hudson, Roland \& Niblock, Chantelle (2018). "Collaborative learning in architectural education: Benefits of combining conventional studio, virtual design studio and live projects", British Journal of Educational Technology, 49(3), 337-353, https://doi.org/10.1111/bjet.12535.

Safari, Hossein \& Baghaei, Abdollah (2018) "Factors Affecting Creativity in Architectural Education Process Based on Computer Aided Design", Frontiers of Architectural Research, 7(1), 100-106.

Uysal, V. Safak \& Topaloglu, Fulden (2017) "Bridging the Gap: A Manual Primer into Design Computing in the Context of Basic Design Education", The International Journal of Art \& Design Education, 36 (1), 21-38. https://doi.org/10.1111/jade.12048

Architecture Accreditation Board (MIAK) web site, http://www.miak.org/, accessed on October, 2018. Council of Higher Education web site, http://www.yok.gov.tr/, accessed on September 2017.

National Architectural Accrediting Board (NAAB) web site, https://www.naab.org/, accessed on October, 2018. 